\title{
The Effect of Android-Based Learning Media on Student Cognitive Levels in Sports Physiology
}

\author{
Mohd. Adrizal ${ }^{1,4,5, *}$ Iskandar $^{2}$, Muhammad Ilham ${ }^{3,5}$ \\ ${ }^{1}$ Master of Sports Education, Faculty of Sports Sciences, Universitas Negeri Yogyakarta, Indonesia \\ ${ }^{2}$ Psychology Education, UIN Sulthan Thaha Saifuddin, Jambi, Indonesia \\ ${ }^{3}$ Psychology, Universitas Gadjah Mada, Sleman, Indonesia \\ ${ }^{4}$ Sport and Health Education, Jambi University, Indonesia \\ ${ }^{5}$ Janur Institute, Jambi, Indonesia \\ *Corresponding author. Email: mohdadrizal50@gmail.com
}

\begin{abstract}
In the current of education research, android-based learning media has been popular and becomes a trend. In Sports Physiology learning process, students have difficulty in acquiring the knowledge since it contains very complex materials. In addition, conventional learning method also becomes one of the factors in influencing the students' difficulty and boredom in the learning process in classroom. This study aimed to determine and prove the use of android-based learning media on influencing students' cognitive level in learning Sports Physiology. The instrument used in this study was a questionnare. This research is a quasi-experiment, the research design used a pretest-posttest control group design. The subjects of this study were 60 students consisted of a control class and an experimental class, which belong to sports coaching education students at University of Jambi. In order to measure the students cognitive level in learning, then an analysis for the students' results was conducted. The results showed that the use of Android-based learning media had a significant influence on the students' cognitive level in the learning process, the average score of the experimental class is higher than the control classes. It can be seen that the significance number for android media obtained from the Anova test by using SPSS 21 software was 0.000 .
\end{abstract}

Keywords: Android, Learning media, Student cognitive levels

\section{INTRODUCTION}

The process of interaction between students and the environment that affects their behavior to be better is an important essence in learning. There are many factors that affect student behavior, two of which are internal factors from oneself and external factors from the environment. The most essential duty of educators is to build the environment which supports the students to be better [1]. One of the government's efforts to improve the quality of education is to revise education courses, such as KTSP courses and 2013 courses. This curriculum emphasizes the competency-based learning systems such as the students should be able to plan, explore, interpret and evaluate their own results [2].

According to the conditions in Sports Education Department at University of Jambi, the learning process should consider the students characteristics, sufficient, amenities, abilities, and needs [3]. Hence, an assessment for the implementation of effective learning to improve students' cognitive level is necessary. One of the courses taught is Sports Physiology. This reveals that more efforts are still needed to improve students' cognitive level, since conventional method is still implemented during the learning process, either in lectures or discussions. The conventional learning method give several impacts, such as the students become more dependent on the lecturer, and consider that the learning process only occurs when the lecturer is attending the class. In addition, the students are not ready to acquire the knowledge and do not participate actively during the teaching and learning process in Sports Physiology class. 
If in essence, education is a very important element for creating high-quality resources, these resources should be smart, peaceful, open, democratic and able to compete to improve Indonesia's welfare. Hope that education is an important tool that can increase the potential of human beings in the community or the surrounding environment, and it is also expected to trigger education in the acquisition of ideal ideals [4]. By having quality human resources, various changes and challenges of globalization can be faced [5]. Hence, in creating an effective and efficient learning situation, learning methods and media which are appropriate for students' characteristics are needed. The choice of the learning method will determine the media that are used in learning process. [6] Learning media can be in form of audio visual media in order to obtain a significant learning experience. Lack of innovation on learning media causes the learning process become monotonous and boring. The information delivered by the lecturer tends to not be acquired optimally due to media limitations.

Nowadays, the development of media is not only printed and computer-based media, but also the media based on mobile devices or what is often called as mobile learning. [7] By developing technology, education can be enabled in unlimited distance and time. Due to the flexibility of mobile learning, it is very important to use mobile learning in supporting teaching and learning activities. Therefore, the learning process can be carried out anytime and anywhere [8]. Generally, the mobilebased learning system using Android can be used as a cheap and effective learning medium to complete the learning process of students [9].

Consistent with this, the use of Android-based learning media is one of the applications of learning styles in the 21st century. [10] Since people are already familiar with the technology itself, learning strategies can be implemented by integrating technology into learning. [11] The use of learning media like Android may help improve students' academic skill in the form of learning outcomes in the domain of cognitive [12]. The highest-level cognitive models have multiple levels, such as sociological scheme of human behavior, personal behavior performance pattern, cognitive models embroiling detailed mechanisms, redisplays and processes, as well as neural circuits, brain areas, and detailed biological information. [13]. This study focuses on students' cognitive level of knowledge, in learning Sports Physiology. Learning about the branch of physiology that specializes in studying functional changes caused by physical exercise certainly requires learning media that are suitable for the learning objectives.

Students still lack of understanding in the learning activities, and it encourages the researchers to know what is really happening in their body [14]. Sports Physiology is an important course for those who work in the field of sports. Sports Physiology examines the changes in organs function, either for temporary (acute) or sedentary time, due to the exercise. Sports Physiology identifies the changes which are caused by a single exercise (acute exercise) or exercises that are done repeatedly (chronic exercise) in order to improve physiological responses for the intensity, duration, frequency of exercise, environmental conditions, and physiological status of the individual. Human effort in keeping its physiology such as avoiding the haze is essential thing [15]. By finding the changes that occur in the body, a person can design an exercise program to get optimal changes [16].

95\% of Android users said they were satisfied with accessing the application, and only 5\% of users felt uncomfortable. Based on these facts, an innovation was made in the learning media by using Android in the learning activities, especially in Sports Physiology course. Therefore, this research intends to calculate and verify the impact of learning based on Android media on students' cognitive level in exercise physiology courses [17].

\section{RESEARCH METHODS}

\subsection{Research Design}

The design model implemented in this study is a pretest posttest-group with control group design. This study was carried out at the University of Jambi, Indonesia. The populations of this research were the fifth semester college sports coach educated students of Jambi. All samples are composed of two categories. For example, an experimental category received treatment during the learning process through the use of Android-based learning media, while a control group received no treatment.

\subsection{Data collection and analysis}

The subjects of this study had taken Sports Physiology course. Then, the students were given an instrument of student cognitive learning achievement test which consisted of 32 items, in order to measure 
students' initial knowledge on cognitive learning outcomes (Pretest). When the learning process is over, other students were asked to work on a cognitive learning outcome test instrument with the similar number of questions and siilar level of difficulty. The indicators of the test instrument were as follows.

Table 1. The indicators of students' results in the cognitive test

\begin{tabular}{|c|c|c|c|}
\hline Lesson Plan & Indicators & $\mathrm{CL}$ & NI \\
\hline $\begin{array}{l}\text { Analyzing } \\
\text { the } \\
\text { relationship }\end{array}$ & $\begin{array}{l}\text { Making the hypothesis } \\
\text { of the influence of } \\
\text { cigarettes. }\end{array}$ & C6 & 1 \\
\hline $\begin{array}{l}\text { between } \\
\text { the } \\
\text { structure of }\end{array}$ & $\begin{array}{l}\text { Interpreting the gas } \\
\text { pressure data in } \\
\text { human's body. }\end{array}$ & C5 & 2 \\
\hline $\begin{array}{l}\text { organs } \\
\text { component } \\
\text { s in the } \\
\text { respiratory }\end{array}$ & $\begin{array}{l}\text { Identifying the organ } \\
\text { functions which have } \\
\text { role in human's } \\
\text { respiratory system. }\end{array}$ & C4 & 9 \\
\hline $\begin{array}{l}\text { system, in } \\
\text { relation to } \\
\text { the }\end{array}$ & $\begin{array}{l}\text { Deciding the kinds of } \\
\text { disease in human's } \\
\text { respiratory system. }\end{array}$ & $\mathrm{C} 3$ & 7 \\
\hline $\begin{array}{l}\text { bioprocess } \\
\text { and } \\
\text { impaired } \\
\text { function }\end{array}$ & $\begin{array}{l}\text { Giving examples of } \\
\text { factors which affect } \\
\text { human's respiratory } \\
\text { frecuency. }\end{array}$ & $\mathrm{C} 2$ & 12 \\
\hline $\begin{array}{l}\text { that can } \\
\text { occur in } \\
\text { humans' } \\
\text { respiratory } \\
\text { system. }\end{array}$ & $\begin{array}{l}\text { Identifying the gas } \\
\text { exchanges in humans' } \\
\text { respiratory system }\end{array}$ & C1 & 1 \\
\hline $\begin{array}{l}\text { Total } \\
\text { numbers }\end{array}$ & & & 32 \\
\hline
\end{tabular}

Explanation:

$\begin{array}{ll}\text { CL } & \text { : Cognitive level } \\ \text { NI } & : \text { The number of item }\end{array}$

The evaluation of student performance intends to determine the effectiveness of Android-based media in exercise physiology courses to improve its effectiveness. The evaluation was conducted by examining the results of pre-test and post-test scores in a limited trial, and analyzed using the Anova SPSS 21 test, as well as the experimental group and control class.

The data was collected by conducting a test. In order to determine students' cognitive abilities in Sports Physiology, the instruments used are in question form. The test was presented to participant to calculate the students' achievement. The experimental class was a number of students that received the treatment by using android media in Sports Physiology course, while the control class was a class that did not receive any treatments, in Sports Physiology course. The students' cognitive learning achievement test consisted of 32 items was given in order to measure students' initial knowledge on cognitive learning (Pretest). Both classes, such as experimental and control class were given two treatments ( $2 \times 90$ minutes). When the learning process is over, the other students were given the cognitive learning achievement test which had the similar number of questions and similar level of difficulty. To obsreve the cognitive changes of students after participating in the learning process, the results were analyzed [18]. This study implemented pretest-posttest control-group research design which can be observed in the Table 2 .

Table 2. Research Design of Pretest-Postest ControlGroup.

\begin{tabular}{|c|c|c|}
\hline \multirow{2}{*}{ Activity } & \multicolumn{2}{|c|}{ Class } \\
\cline { 2 - 3 } & Control Class & Experiment Class \\
\hline Pretest & F1 & F1 \\
\hline Treatment & W1 & W2 \\
\hline Posttest & F2 & F2 \\
\hline
\end{tabular}

Explanation:

F1 : Pretest of cognitive

F2 : Posttest of cognitive

W1 : Applying power point only as media in leraning.

W2 : Applying power point and Android as media in learningsport fisiology

The calculations on the students' cognitive improvement were categorized by using the normalized gain quation [18].

Gain score $(\mathrm{g})=\frac{\text { Posttest score-Pretest score }}{\text { Maximum score-pretest score }}$ 
To observe the progress of students' cognitive level between experimental and control class, the data was analyzed by using independent sample $t$ test. The prerequisite tests that should be performed are normality and homogeneity tests. Use descriptive quantitative analysis techniques to analyze the data. The statistical analysis in SPSS 21 was used to quantitative analysis, and pass the gain score test and the Anova test of the sports performance sub-material post-test to calculate the number of students who have reached the minimum proficiency standard to measure student performance and view the effectiveness of Android-based media. The Windows version of SPSS is used for statistical testing with 95\% confidence. The hypotheses of this study are as follows:

Ho: There was no significant difference in the cognitive level of the experimental class and the control group.

\section{RESULTS AND DISCUSSION}

Evaluation data on the students' result can be seen in Table 3.

Table 3. Distribution of Pretest and Posttest Results for Experiment and Control Classes

\begin{tabular}{|c|c|c|c|c|}
\hline $\begin{array}{c}\text { Statistic } \\
\text { Data }\end{array}$ & $\begin{array}{c}\text { Pretest } \\
\text { Exp. }\end{array}$ & $\begin{array}{c}\text { Pretest } \\
\text { Control }\end{array}$ & $\begin{array}{c}\text { Posttest } \\
\text { Exp. }\end{array}$ & $\begin{array}{c}\text { Posttest } \\
\text { Control }\end{array}$ \\
\hline $\mathrm{N}$ & 30 & 30 & 30 & 30 \\
\hline Mean & 43.56 & 44.96 & 78.74 & 63.78 \\
\hline STD & 9.78 & 6.13 & 7.42 & 8.54 \\
\hline Max & 55.56 & 55.56 & 93.33 & 77.78 \\
\hline Min & 22.22 & 28.89 & 62.22 & 48.89 \\
\hline Modus & 53.33 & 48.89 & 86.67 & 75.56 \\
\hline Median & 45.55 & 45.55 & 77.78 & 64.44 \\
\hline
\end{tabular}

From the average score after the test, it can be seen that there is a difference between the academic performance of the experimental class that uses Android-based media to receive treatment in the exercise physiology course and the control group that does not receive any treatment. By using SPSS 21 to calculate the score, it can be seen that the average score of the experimental category is higher than the control category.

The success of Android-based media in improving students' achievement was indicated when the number of students who get a post-test score $\geq 75$ reaches $\geq 75 \%$ of all students, and have reached the Minimum Mastery Criteria. The percentage of

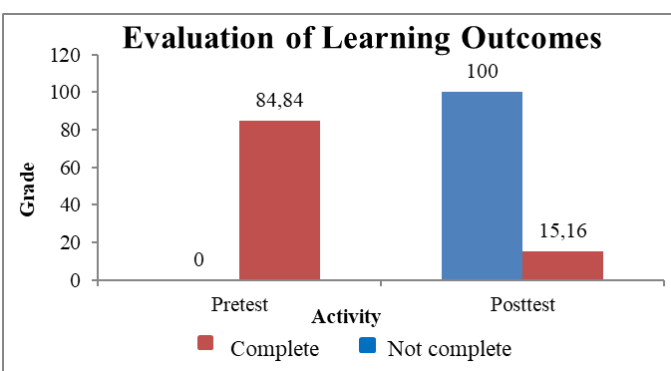

students who have reached the Minimum Matery Criteria limit is presented in the following graph.

Figure 1 Graph of increasing the Minimum Matery Criteria for Student Experiment Class

According to the analysis results, it shows that more than $75 \%$ of students have reached the "minimum mastery standard" limit. It can be concluded that Android-based media can be effectively used in the learning process of exercise physiology to improve students' academic performance. The results of the Anova test prove this.

\subsection{The Normality Test of the Data Distribution}

Normality tests were performed on the pre-test and post-test scores of the experimental group and the control group. The following data shows the pre-test and post-test scores of the experimental class and the control group.

Table 4. Normality test results of pre-test and posttest data for for sports physiology sub-material

\begin{tabular}{|c|c|r|c|}
\hline \multirow{2}{*}{ Data } & \multicolumn{2}{|c|}{$\begin{array}{c}\text { Kolmogorov- } \\
\text { Smirnov }(\mathrm{K}-\mathrm{S})\end{array}$} & \multirow{2}{*}{ Exp. } \\
\cline { 2 - 4 } & $\mathrm{df}$ & Sig. & \\
\hline $\begin{array}{c}\text { Pretest } \\
\text { Experiment }\end{array}$ & 29 & .097 & $\mathrm{P}>0.05$ normal \\
\hline $\begin{array}{c}\text { Pretest } \\
\text { Control }\end{array}$ & 29 & .200 & $\mathrm{P}>0.05$ normal \\
\hline $\begin{array}{c}\text { Posttest } \\
\text { Experiment }\end{array}$ & 29 & .056 & $\mathrm{P}>0.05$ normal \\
\hline $\begin{array}{c}\text { Posttest } \\
\text { Control }\end{array}$ & 29 & .086 & $\mathrm{P}>0.05$ normal \\
\hline
\end{tabular}

Based on these data, it can be concluded that since $p>0.05$, all pre-test and post-test data of the experimental category and the control category are normally distributed. 


\subsection{Variance Homogeneity Test}

The test for homogeneity of variance is designed to determine the similarity of variance between two categories. The homogeneity test results are shown in Table 5.

Table 5. Results of Homogeneity VariantsTest of Pretest and Posttest Data or Sports Physiology submaterial

\begin{tabular}{|c|c|c|c|c|c|}
\hline Data & Levene & df1 & df2 & Sig. & Exp. \\
\hline Pretest & 8.847 & 1 & 58 & .104 & $\begin{array}{c}\text { Sig }>0.05 \\
\text { homogen }\end{array}$ \\
\hline Posttest & .369 & 1 & 58 & .546 & $\begin{array}{c}\text { Sig }>0.05 \\
\text { homogen }\end{array}$ \\
\hline
\end{tabular}

Based on the data, it can be concluded that all pre-test and post-test data of the experimental class and the control class are are homogeneous because p> 0.05 .

\subsection{Anova Test}

The next step is to test the hypothesis by using Anova statistics after all the prerequisite tests have been met. This test aims to determine the effectiveness of android media in sport physiology courses to improve students' academic performance. Table 6 lists the Anova test results.

Table 6. Test of Between Subjecst Effect Anova regarding Posttest for Sports Physiology SubMaterial

\begin{tabular}{|c|c|c|}
\hline Source & Dependent variable & Sig. \\
\hline Pretest & Posttest & 0.000 \\
\hline Android Media & Posttest & 0.000 \\
\hline
\end{tabular}

According to the results of the Anova test, on the post-test of the sub-materials of exercise physiology, it can be found that the significance value of android media obtained from the Anova test using SPSS 21 software is 0.000 . This indicates that the null hypothesis is invalid and rejected. At the same time, another hypothesis was accepted, that is, "there is a significant difference between the learning cognitive level of the experimental class and the control group." Therefore, Android-based media can effectively improve students' cognitive learning performance.

The students' achievement after being taught by using Android-based media was calculated by the normalized gain score formula. Normalized gain score calculation results can be seen in Table 7 .
Table 7. Calculation of gain score evaluation of learning outcomes

\begin{tabular}{|c|c|c|}
\hline Grade & Experiment class & Control class \\
\hline Pretest & 43.56 & 44.96 \\
\hline Posttest & 78.74 & 63.77 \\
\hline Gain score & 0.61 & 0.34 \\
\hline Category & medium & Medium \\
\hline
\end{tabular}

These data show that the improvement of students' academic performance in both classes is moderate, but in the experimental class, the improvement of cognitive learning performance is higher than that of the control group. In addition, there is also a difference between the average scores of the students in the control class and the experimental class [19]. Many previous studies have shown that students' learning motivation is a factor that affects students' academic performance [20].

Learning activities is a process of someone who is trying to obtain a behavior change that is sedentary [21]. The students' achievement in knowledge and competence can be seen from their changes in perception and behavior, such as behavior improvement [22]. The difference in student learning achievement is influenced by the effectiveness of the teaching materials [23].

It is expected that Android-based media will be able to promote the learning activities of the students of the School of Physical Education of Jambi University and improve their cognitive learning performance, especially in the exercise physiology course. Technology can be used to support the learning process, support communication arrangements, evaluate learning activities, and create learning materials [24]. This is in line with the the function of instructional media is to facilitate students in learning, attract students' attention, and provide more experiences in order to change the abstract materials into the more concrete ones [25]. It is similar to argument which stated that students will more easily learn concrete things rather than abstract ones, in order to increase students' understanding which has an impact on increasing cognitive learning outcomes [26]. The mobile learning based model can improve students' achievement in the curriculum and the learning course [27].

The difference in cognitive learning achievements between the experimental and the control class is due to the differences in the treatment. The experimental class that were taught by using Android-based media 
in two meetings showed a significant improvement in cognitive learning achievement, since students were easier to understand the material of Sports Physiology through the Android-based media that can visualize processes that cannot be directly observed. Students can understand the concepts and processes in Sports Physiology material simply through learning media, because of the pictures, animations, and videos that facilitate the students in understanding the material. In addition, students can measure their knowledge after learning through quizzes and questions in the android media. By receiving the treatments in two meetings, students were able to understand the materials in Sports Physiology because students have received an explanation from the lecturer and reviewed concepts that are already in the textbook. This learning process makes the knowledge acquired by students through memorization. [28] This study has similar important results. The results show that the use of media can improve students' cognitive learning outcomes after participating in media tutoring, which has reached the lowest proficiency score in terms of immune system materials, which proves this.

Learning media can improve students' academic performance [29]. The media has the ability to attract students' attention, so it can improve students' academic performance so that they can focus on the content of the course. Visual symbols or images help them understand and remember the information or messages contained in images and animations. Cognitive function and compensation function can help students with weak reading ability organize text information and recall it. The use of images, animations, texts and videos on android media in exercise physiology has achieved these functions and improved the cognitive learning outcomes of students.

Learning media that have been developed have several advantages, such as: (a) easy to use; (b) materials presented in small and complete units; clear illustrated examples can be used; (c) able to display or visualize biological processes; and (d) can be applied any times.

\section{CONCLUSIONS}

Android media on Sports Physiology course is effective in improving cognitive achievement of students in Sports Education Department, University of Jambi, which showed a significant difference in the cognitive learning achievement, between the experimental and control class with $\mathrm{p}<0.05$, and the improvement in cognitive learning achievement of experimental class belonged to moderate category.

\section{REFERENCES}

[1] E. Mulyasa, Becoming A Professional Teacher Creating Creative and Fun Learning, Remaja Rosdakarya, 2008.

[2] E.S. Ketut, L.I. Wayan, S.I. Wayan, Pengaruh Media CD Interaktif Berbantuan LKS terhadap Kognitif dan Hasil Belajar IPA Kelas V di SD 1, 2,5 Banyuasri-Singaraja, Jurnal Pendidikan Dasar Ganesha 3(1) (2013) 1-11.

[3] M. Adrizal, Gunturan, D.M. Pahlifi, The use of android media in improving students' motivation in learning sports physiology, in: Journal of Physics: Conference Series, vol. 1440, IOP Publishing, Bristol, 2020, pp. 1-8. DOI: $\quad$ https://doiorg/101088/1742$\underline{6596 / 1440 / 1 / 012075}$

[4] M. Habibi, D. Lasia, M. Oktafia, M. Ilham, Habits of Mind Strategies for Enhancing Students' Math Problem Solving Skill JTAM, Jurnal Teori dan Aplikasi Matematika 4(1) (2020) 182-189. DOI: https://doi.org/10.31764/jtam.v4i2.2590

[5] M. Budiawan, Pengaruh Model Pembelajaran Kooperatif Tipe Jigsaw dan Kognitif Belajar terhadap Prestasi Belajar Ilmu Fisiologi Olahraga, Jurnal Pendidikan Indonesia 2(1) (2013) 138-144. DOI: http://dx.doi.org/10.23887/jpiundiksha.v2i1.1410

[6] D.G. Ramadhani, B. Mulyani, S.B. Utomo, Pengaruh Penggunaan Media Mobile Learning Berbasis Android dan LKS dalam Model Pembelajaran Student Team Achivement Division (Stad) terhadap Prestasi Belajar ditinjau dari Kemampuan Memori pada Materi Pokok Sistem Koloid Kelas XI SMA Negeri 2 Purwokerto, Jurnal Pendidikan Kimia 5(1) (2016) 16-25.

[7] Iskandar, D. Sastradika, Jumadi, Pujianto, D. Defrianti, Development of creative thinking skills through STEM-based instrumen in senior high school student, in: Journal of Physics: Conference Series, vol. 1567, IOP Publishing, Bristol, 2020, pp. 1-6. DOI: doi:10.1088/1742$\underline{6596 / 1567 / 4 / 042043}$ 
[8] Y.D. Prasetyo, R. Yektyastuti, J. Ikhsan, K.H. Sugiyarto, Pengaruh penggunaan media pembelajaran kimia berbasis android terhadap peningkatan kognitif belajar siswa SMA, in: Prosiding Seminar Nasional Pendidikan Sains, vol. 2, Universitas Sebelas Maret, Surakarta, 2015, pp. 252-258.

[9] K.T. Martono, O.D. Nurhayati, Implementation of Android Based Mobile Learning Application as A Flexible Learning Media, International Journal of Computer Science Issues 11(3) (2014) 168-174.

[10] S.C. Wibawa, S. Schulte, Beauty Media Learning using Android Mobile Phone, International Journal of Innovative Research in Advanced Engineering 2(11) (2015) 20-26.

[11] D.M. Pahlifi, H. Nurcahyo, The effect of android-based pictorial biology dictionary on students' motivation on topic of invertebrate, in: Journal of Physics: Conference Series, vol. 1241, IOP Publishing, Bristol, 2019. pp. 12-48. DOI: $\quad$ https://doi.org/10.1088/1742$\underline{6596 / 1241 / 1 / 012048}$

[12] J.N. Calimag, P.A. Mugel, R.S. Conde, L.B. Aquino, Ubquitous Learning Environment Using Android Mobile Application, International Journal of Research in Engineering \& Technology 2(2) (2014) 119-128.

[13] R. Yektyastuti, J. Ikhsan, Pengembangan Media Pembelajaran Berbasis Android pada Materi Kelarutan untuk Meningkatkan Performa Akademik Siswa SMA, Jurnal Inovasi Pendidikan IPA 2(1) (2016) 88-99. DOI: https://doi.org/10.21831/jipi.v2i1.10289

[14] R. Sun, L.A. Coward, M.J. Zenzen, On Levels of Cognitive Modelling, Philosophical Psychology 18(5) (2005) 613-637. DOI: https://doi.org/10.1080/09515080500264248

[15] L.P. Sari, Suparno, M. Fatharani, D.M. Pahlifi, M. Adrizal, D.S. Luliyanti, Effectiveness of air filter equipment based on water Hyacinth on combustion smoke, in: Journal of Physics: Conference Series, vol. 1511, IOP Publishing, Bristol, 2020, pp. 12-61. DOI: https://doi.org/10.1088/1742$\underline{6596 / 1511 / 1 / 012061}$

[16] D.M. Pahlifi, M. Fatharani, Android-Based Learning Media on Human Respiratory System Material for High School Students, Jurnal Inovasi Pendidikan IPA 5(1) (2019) 109-116. DOI: $\underline{\text { https://doi.org/10.21831/jipi.v5i1.25111 }}$
[17] N. Anggriawan, Peran Fisiologi Olahraga dalam Menunjang Prestasi, Jurnal Olahraga Prestasi 11(2) (2015) 8-18. DOI: https://doi.org/10.21831/jorpres.v11i2.5724

[18] W. Wiersma, S. Jurs, Research Methods in Education Ninth Edition, Pearson Education India, 2009.

[19] Meiristiy, Vivin, Pengaruh Sumber Belajar (Learning Resources by Design dan Learning Resources by utilization) terhadap Prestasi Belajar Siswa pada Mata Pelajaran Sejarah Kelas X IPS di SMA Negeri 2 Mojokerto, Avatara 4(3) (2016) 1046-1058.

[20] Anderson, C. James, Effect of Problem-Based Learning on Knowledge Acquisition, Knowledge Retention, and Critical Thinking Ability of Agriculture Students in Urban Schools, University of Missouri, 2007.

[21] A. Susanto, Teori Belajar \& Pembelajaran di Sekolah Dasar, Kencana Prenada Media Group, 2013.

[22] O. Hamalik, Proses Belajar Mengajar, Bumi Aksara, 2005.

[23] N. Angko, Mustaji, Pengembangan Bahan Ajar dengan Model ADDIE untuk Mata Pelajaran Matematika Kelas 5 SDS Mawar Sharon Surabaya, Kwangsan Jurnal Teknologi Pendidikan 1(1) (2013) 1-15. DOI: https://doi.org/10.31800/jtp.kw.v1n1.p1--15

[24] C.K. Nuraini, M. Faaizah, C.P. Naim, Personalized Learning Environment (PLE) Experience in the 21st Century, 4th World Congress on Information and Communication Technology, 2014.

[25] Asnawir, B. Usman, Media Pembelajaran Ciputat Pers, 2002.

[26] Daryanto, Media Pembelajaran, Gavamedia, 2010.

[27] Rusman, Pengembangan Model E-Learning untuk Meningkatkan Hasil Belajar Mahasiswa. Kwangsan Jurnal Teknologi Pendidikan 4(1) (2016) 1-15. DOI: https://doi.org/10.31800/jtp.kw.v4n1.p1--15

[28] R.D. Astuti, Penyusunan Media Pembelajaran Remedial pada Materi Sistem Kekebalan Tubuh Menggunakan Software Lectora untuk Siswa Kelas XI IPA Semester 2, Skripsi, FMIPA UNY, 2013.

[29] N. Sudjana, A. Rivai, Educational Media, Balai Pustaka, 2002. 